\title{
Genetic diversity analysis of Varronia curassavica Jacq. accessions using ISSR markers
}

\author{
F.A. Brito ${ }^{1}$, D.A.C. Nizio' ${ }^{1}$ A.V.C. Silva ${ }^{2}$, L.E.C. Diniz ${ }^{2}$, A.R.C. Rabbani', \\ M.F. Arrigoni-Blank ${ }^{1}$, S.V. Alvares-Carvalho ${ }^{1}$, G.M. Figueira ${ }^{4}$, \\ I. Montanari Júnior ${ }^{4}$ and A.F. Blank ${ }^{1}$ \\ ${ }^{1}$ Laboratório de Recursos Genéticos Vegetais e Óleos Essenciais, \\ Departamento de Engenharia Agronômica, \\ Universidade Federal de Sergipe, São Cristóvão, SE, Brasil \\ ${ }^{2}$ Laboratório de Biotecnologia Molecular, \\ Embrapa Tabuleiros Costeiros, Aracaju, SE, Brasil \\ ${ }^{3}$ Instituto Federal da Bahia, Porto Seguro, BA, Brasil \\ ${ }^{4}$ Centro Pluridisciplinar de Pesquisas Químicas Biológicas e Agrícolas, \\ Universidade Estadual de Campinas, Campinas, SP, Brasil \\ Corresponding author: A.F. Blank \\ E-mail: afblank@ufs.br
}

Genet. Mol. Res. 15 (3): gmr.15038681

Received March 31, 2016

Accepted May 25, 2016

Published September 2, 2016

DOI http://dx.doi.org/10.4238/gmr.15038681

Copyright $(C 2016$ The Authors. This is an open-access article distributed under the terms of the Creative Commons Attribution ShareAlike (CC BY-SA) 4.0 License

ABSTRACT. Varronia curassavica Jacq. is a medicinal and aromatic plant from Brazil with significant economic importance. Studies on genetic diversity in active germplasm banks (AGB) are essential for conservation and breeding programs. The aim of this study was to analyze the genetic diversity of $V$. curassavica accessions of the AGB of Medicinal and Aromatic Plants of the Federal University of Sergipe (UFS), using inter-simple sequence repeat molecular markers. Twentyfour primers were tested, and 14 were polymorphic and informative, resulting in 149 bands with $97.98 \%$ polymorphism. The UPGMA 
dendrogram divided the accessions into Clusters I and II. Jaccard similarity coefficients for pair-wise comparisons of accessions ranged between 0.24 and 0.78 . The pairs of accessions VCUR-001/VCUR-503, VCUR-001/VCUR-504, and VCUR-104/VCUR-501 showed relatively low similarity (0.24), and the pair of accessions VCUR-402/VCUR403 showed medium similarity (0.78). Twenty-eight accessions were divided into three distinct clusters, according to the STRUCTURE analysis. The genetic diversity of $V$. curassavica in the AGB of UFS is low to medium, and it requires expansion. Accession VCUR-802 is the most suitable for selection in breeding program of this species, since it clearly represents all of the diversity present in the AGB.

Key words: Varronia curassavica; Conservation; Diversity; ISSR

\section{INTRODUCTION}

Varronia curassavica Jacq. (with synonym Cordia verbenacea DC.) is popularly known as "erva-baleeira." It is a medicinal and aromatic plant in the Cordiaceae family (previously Boraginaceae) and is native to Central and South America, occurring mainly in Brazil (Barroso et al., 2002; Gasparino and Barros, 2009; Gilbert and Favoreto, 2012). It is a perennial, highly branched shrub that can reach 1.5 to $2.5 \mathrm{~m}$ in height, and it is widely used in popular medicine to treat arthritis (Lorenzi and Matos, 2008). The Brazilian National Health Surveillance Agency approved the first herbal medicine produced from an essential oil of this plant in 2004, with the active compound, $\alpha$-humulene, showing anti-inflammatory activity (Feijó et al., 2014). This shows how important this species is for the pharmaceutical industry. In a study of native populations of $V$. curassavica in the State of Sergipe, the authors reported a high chemical diversity in essential oils, and five chemical groups were detected (Nizio et al., 2015). This finding, together with the medical importance of the species, and the loss of plant genetic resources due to human activities, highlights the importance of conserving the diversity of this species. The partial conservation of medicinal or agricultural plant species can be performed in active germplasm banks (AGB). A representative sample of the genetic variability of the species can be conserved, allowing the identification and selection of accessions of interest that can be used to develop superior cultivars through breeding programs (Blank, 2013).

The genetic diversity of a species can be assessed through various types of molecular markers, including inter-simple sequence repeats (ISSRs). These molecular markers use short repeated sequences of DNA to amplify anonymous loci and do not require prior knowledge of the genome. Because they are dominant loci, it is not possible to distinguish heterozygotes from homozygotes; however, multiple loci can be produced from each amplification with polymerase chain reaction (PCR; Goulão and Oliveira, 2001). Several genetic diversity studies on medicinal plants, both in natural populations and in collections of germplasm banks, have been carried out using ISSRs, such as studies on Capparis spinosa, Eucommia ulmoides, and Pogostemon cablin (Liu et al., 2015; Yu et al., 2015; Sandes et al., 2016).

Universidade Federal de Sergipe (UFS) studied the chemical diversity of populations of $V$. curassavica from the State of Sergipe, and genetic resources from those populations are conserved in an AGB that was implemented in 2012. The present study is the first investigation of genetic diversity of this species, using ISSR markers.

Genetics and Molecular Research 15 (3): gmr.15038681 
Thus, the aim of this study was to analyze the genetic diversity of $V$. curassavica accessions of the AGB of Medicinal and Aromatic Plants of UFS using ISSR molecular markers. This information will then be used to prioritize accessions for conservation and genetic improvement of the species.

\section{MATERIAL AND METHODS}

\section{Plant material}

After exploitation and collection of plant material from the State of Sergipe in the municipalities of Graccho Cardoso, Tobias Barreto, São Cristóvão, Japaratuba, Tomar do Geru, Itabi, Cedro de São João, and Itabaiana, and with five accessions from seedling exchange with the AGB of Centro Pluridisciplinar de Pesquisas Químicas, Biológicas e Agrícolas, collected in the State of São Paulo (Table 1), the V. curassavica collection was implemented within the AGB of medicinal and aromatic plants of UFS. The AGB is located at the Research Farm Campus Rural da UFS, in São Cristóvão, State of Sergipe, Brazil (11 $\left.{ }^{\circ} 00^{\prime} \mathrm{S} ; 3^{\circ} 12^{\prime} \mathrm{W}\right)$, with 28 accessions of $V$. curassavica.

Fresh and young leaves of each accession from the AGB were collected, wrapped in sterile gauze, and packed in ice at the time of collection, to prevent oxidation. Afterwards, they were frozen at $-80^{\circ} \mathrm{C}$ until lyophilization in a LioTop L101 (Liobras, São Carlos, SP, Brazil). After lyophilization, samples were stored in a desiccator containing silica gel until DNA extraction.

\begin{tabular}{|c|c|c|}
\hline Accession code & Source/origin within Brazil (municipality, state) & Georeferenced information \\
\hline VCUR-001 & $\begin{array}{l}\text { Donated by Multidisciplinary Center for Chemical, Biological and Agricultural Research, } \\
\text { Campinas State University, Campinas, São Paulo }\end{array}$ & - \\
\hline VCUR-002 & Ubatuba, São Paulo & $23^{\circ} 32^{\prime} 18.0^{\prime \prime} \mathrm{S} ; 45^{\circ} 03^{\prime} 73.4^{\prime \prime} \mathrm{W}$ \\
\hline VCUR-003 & Ilha Comprida, São Paulo & $25^{\circ} 02^{\prime} 44.0^{\prime \prime} \mathrm{S} ; 47^{\circ} 53^{\prime} 17.0^{\prime \prime} \mathrm{W}$ \\
\hline VCUR-004 & Mongágua, São Paulo & $24^{\circ} 08^{\prime} 00.0^{\prime \prime} \mathrm{S} ; 46^{\circ} 42^{\prime} 54.0^{\prime \prime} \mathrm{W}$ \\
\hline VCUR-005 & Ilha Comprida, São Paulo & $24^{\circ} 43^{\prime} 08.0^{\prime \prime} \mathrm{S} ; 47^{\circ} 30^{\prime} 36.0^{\prime \prime} \mathrm{W}$ \\
\hline VCUR-101 & Graccho Cardoso, Sergipe & $10^{\circ} 14^{\prime} 48.5^{\prime \prime} \mathrm{S} ; 37^{\circ} 12^{\prime} 52.8^{\prime \prime} \mathrm{W}$ \\
\hline VCUR-102 & Graccho Cardoso, Sergipe & $10^{\circ} 14^{\prime} 47.6^{\prime \prime} \mathrm{S} ; 37^{\circ} 12^{\prime} 52.8^{\prime \prime} \mathrm{W}$ \\
\hline VCUR-103 & Graccho Cardoso, Sergipe & $10^{\circ} 14^{\prime} 47.9^{\prime \prime} \mathrm{S} ; 37^{\circ} 12^{\prime} 52.2^{\prime \prime} \mathrm{W}$ \\
\hline VCUR-104 & Graccho Cardoso, Sergipe & $10^{\circ} 14^{\prime} 46.1^{\prime \prime} \mathrm{S} ; 37^{\circ} 12^{\prime} 52.8^{\prime \prime} \mathrm{W}$ \\
\hline VCUR-105 & Graccho Cardoso, Sergipe & $10^{\circ} 14^{\prime} 46.4^{\prime \prime} \mathrm{S} ; 37^{\circ} 13^{\prime} 26.6^{\prime \prime} \mathrm{W}$ \\
\hline VCUR-201 & Tobias Barreto, Sergipe & $11^{\circ} 03^{\prime} 54.2^{\prime \prime} \mathrm{S} ; 38^{\circ} 03^{\prime} 21.1^{\prime \prime} \mathrm{W}$ \\
\hline VCUR-202 & Tobias Barreto, Sergipe & $11^{\circ} 04^{\prime} 10.1^{\prime \prime} \mathrm{S} ; 38^{\circ} 04^{\prime} 03.4^{\prime \prime} \mathrm{W}$ \\
\hline VCUR-301 & São Cristóvão, Sergipe & $10^{\circ} 54^{\prime} 26.3^{\prime \prime} \mathrm{S} ; 37^{\circ} 11^{\prime} 53.1 " \mathrm{~W}$ \\
\hline VCUR-302 & São Cristóvão, Sergipe & $10^{\circ} 54^{\prime} 59.7^{\prime \prime} \mathrm{S} ; 37^{\circ} 11^{\prime} 16.3^{\prime \prime W}$ \\
\hline VCUR-303 & São Cristóvão, Sergipe & $10^{\circ} 54^{\prime} 48.5^{\prime \prime} \mathrm{S} ; 37^{\circ} 11^{\prime} 50.3^{\prime \prime} \mathrm{W}$ \\
\hline VCUR-401 & Japaratuba, Sergipe & $10^{\circ} 38^{\prime} 05.4^{\prime \prime} \mathrm{S} ; 36^{\circ} 55^{\prime} 10.5^{\prime \prime} \mathrm{W}$ \\
\hline VCUR-402 & Japaratuba, Sergipe & $10^{\circ} 37^{\prime} 59.9^{\prime \prime} \mathrm{S} ; 36^{\circ} 55^{\prime} 16.1^{\prime \prime} \mathrm{W}$ \\
\hline VCUR-403 & Japaratuba, Sergipe & $10^{\circ} 37^{\prime} 39.0^{\prime \prime} \mathrm{S} ; 36^{\circ} 55^{\prime} 25.8^{\prime \prime} \mathrm{W}$ \\
\hline VCUR-404 & Japaratuba, Sergipe & $10^{\circ} 37^{\prime} 37.8^{\prime \prime} \mathrm{S} ; 36^{\circ} 56^{\prime} 00.0^{\prime \prime} \mathrm{W}$ \\
\hline VCUR-501 & Tomar do Geru, Sergipe & $11^{\circ} 21^{\prime} 12.0^{\prime \prime} \mathrm{S} ; 37^{\circ} 50^{\prime} 59.0^{\prime \prime} \mathrm{W}$ \\
\hline VCUR-502 & Tomar do Geru, Sergipe & $11^{\circ} 19^{\prime} 17.1^{\prime \prime} \mathrm{S} ; 37^{\circ} 52^{\prime} 02.4^{\prime \prime} \mathrm{W}$ \\
\hline VCUR-503 & Tomar do Geru, Sergipe & $11^{\circ} 19^{\prime} 05.2^{\prime \prime} \mathrm{S} ; 37^{\circ} 52^{\prime} 17.5^{\prime \prime} \mathrm{W}$ \\
\hline VCUR-504 & Tomar do Geru, Sergipe & $11^{\circ} 19^{\prime} 01.7^{\prime \prime} \mathrm{S} ; 37^{\circ} 52^{\prime} 25.0^{\prime \prime} \mathrm{W}$ \\
\hline VCUR-505 & Tomar do Geru, Sergipe & $11^{\circ} 19^{\prime} 04.0^{\prime \prime} \mathrm{S} ; 37^{\circ} 51^{\prime} 51.8^{\prime \prime} \mathrm{W}$ \\
\hline VCUR-601 & Itabi, Sergipe & $10^{\circ} 09^{\prime} 24.9^{\prime \prime} \mathrm{S} ; 37^{\circ} 08^{\prime} 27.0^{\prime \prime} \mathrm{W}$ \\
\hline VCUR-701 & Cedro de São João, Sergipe & $10^{\circ} 18^{\prime} 06.9^{\prime \prime} \mathrm{S} ; 36^{\circ} 53^{\prime} 27.7^{\prime \prime} \mathrm{W}$ \\
\hline VCUR-801 & Itabaiana, Sergipe & $10^{\circ} 50^{\prime} 27.6^{\prime \prime} \mathrm{S} ; 37^{\circ} 12^{\prime} 49.3^{\prime \prime \mathrm{W}}$ \\
\hline VCUR-802 & Itabaiana, Sergipe & $10^{\circ} 48^{\prime} 28.9^{\prime \prime} \mathrm{S} ; 37^{\circ} 15^{\prime} 48.6^{\prime \prime} \mathrm{W}$ \\
\hline
\end{tabular}




\section{DNA extraction and ISSR amplification}

DNA extraction was carried out using the $2 \%$ CTAB method (Doyle and Doyle, 1990), modified by Alzate-Marin et al. (2005). DNA quantification was carried out using a NanoDrop 2000c (Thermo Fisher Scientific, Wilmington, DE, USA), and samples were diluted to a standard concentration. ISSR primers used in this study were produced by Eurofins MWG Operon (Operon Technologies, Louisville, KY, USA), IDT (Integrated DNA Technologies, Coralville, IA, USA), and Invitrogen (Thermo Fisher Scientific, Carlsbad, CA, USA). Twentyfour primers were tested for PCR amplification. Reactions were carried out in a total volume of $20 \mu \mathrm{L}$ containing $1.0 \mu \mathrm{L}$ genomic DNA $(10 \mathrm{ng} / \mu \mathrm{L}), 0.2 \mu \mathrm{L}$ Taq polymerase from Thermus aquaticus recombinant, expressed in Escherichia coli (Sigma-Aldrich) (0.05 units $/ \mu \mathrm{L}), 2 \mu \mathrm{L}$ $10 \mathrm{X}$ buffer (100 mM Tris-HCl, $\mathrm{pH} 8.3,500 \mathrm{mM} \mathrm{KCl}, 15 \mathrm{mM} \mathrm{MgCl}$ and $0.01 \%$ gelatin) (Sigma-Aldrich, St. Louis, MO, USA), $0.4 \mu \mathrm{L}$ dNTP $(2.5 \mathrm{mM}), 1.0 \mu \mathrm{L}$ primer (25.0 pmol), and $15.4 \mu \mathrm{L}$ autoclaved ultrapure water.

Amplification was carried out in a ProFlex PCR System thermocycler (Thermo Fisher Scientific, Applied Biosystems, Foster City, CA, USA) programmed with the following protocol: $5 \mathrm{~min}$ at $94^{\circ} \mathrm{C} ; 45$ cycles of $40 \mathrm{~s}$ at $94^{\circ} \mathrm{C}, 30 \mathrm{~s}$ ranging from $50.4^{\circ}$ to $53^{\circ} \mathrm{C}$ (using the annealing temperature of each primer; Table 2), and $1 \mathrm{~min}$ at $72^{\circ} \mathrm{C}$; and a final extension for $7 \mathrm{~min}$ at $72^{\circ} \mathrm{C}$. Amplification products were subjected to electrophoresis on a $1.5 \%$ agarose gel, stained with ethidium bromide, visualized under ultraviolet light, and photographed. Molecular weights were estimated using a Ludwig DNA scale of $1 \mathrm{~kb}$ for each primer.

Table 2. ISSR primers, their sequence, annealing temperature, and the amplified products used for genetic diversity analysis of Varronia curassavica.

\begin{tabular}{|c|c|c|c|c|c|c|}
\hline Primer name & Sequence $\left(5^{\prime}-3^{\prime}\right)$ & Length (bp) & $\begin{array}{c}\text { Annealing } \\
\text { temperature }\left({ }^{\circ} \mathrm{C}\right)\end{array}$ & $\begin{array}{c}\text { Total number of } \\
\text { bands }\end{array}$ & $\begin{array}{c}\text { Number of } \\
\text { polymorphic bands }\end{array}$ & $\%$ polymorphism \\
\hline ISSR1 & CAC ACA CAC ACA GG & $100-400$ & 51.5 & 11 & 11 & 100.0 \\
\hline ISSR2 & CTC TCT CTC TCT CTC TAC & $100-350$ & 51.5 & 13 & 13 & 100.0 \\
\hline ISSR3 & CTC TCT CTC TCT CTC TTG & $850-2000$ & 51.5 & 10 & 10 & 100.0 \\
\hline ISSR4 & CAC ACA CAC ACA AC & $250-350$ & 51.5 & 7 & 7 & 100.0 \\
\hline ISSR5 & CTC TCT CTC TCT CTC TGC & $150-350$ & 51.5 & 13 & 13 & 100.0 \\
\hline ISSR6 & CAC ACA CAC ACA AG & $50-450$ & 51.5 & 12 & 11 & 91.7 \\
\hline UBC810 & GAG AGA GAG AGA GAG AT & $200-700$ & 50.4 & 12 & 12 & 100.0 \\
\hline UBC811 & GAG AGA GAG AGA GAG AC & $100-350$ & 53.0 & 6 & 6 & 100.0 \\
\hline UBC834 & AGA GAG AGA GAG AGY T & $1000-2000$ & 52.8 & 11 & 11 & 100.0 \\
\hline UBC841 & GAG AGA GAG AGA GAG AYC & $500-1000$ & 52.0 & 11 & 11 & 100.0 \\
\hline UBC845 & CTC TCT CTC TCT CTC TRG & $400-2000$ & 51.5 & 12 & 12 & 100.0 \\
\hline UBC855 & ACA CAC ACA CAC ACY T & $250-1000$ & 53.0 & 17 & 17 & 100.0 \\
\hline UBC857 & ACA CAC ACA CAC ACY G & $200-1000$ & 53.0 & 9 & 7 & 77.8 \\
\hline UBC 858 & TGT GTG TGT GTG TGT GRT & $450-1000$ & 53.0 & 5 & 5 & 100.00 \\
\hline
\end{tabular}

\section{Data analysis}

For the analysis and interpretation of the gel, only the clearly-visible bands were used. Loci were identified as present (1) or absent (0) in each accession, and this binary data matrix was used for the analyses.

Similarity coefficients were calculated using the Jaccard index (Jaccard, 1908). NTSYSpc 2.0 (Rohlf, 2001) was used to construct a dendrogram, using the unweighted pair group method with arithmetic mean (UPGMA). The Shannon index (I) e o marker index (MI) were calculated using the software GENALEX 6.5 (Peakall and Smouse, 2012). 
STRUCTURE v.2.3.3 was used to analyze genetic structure using a Bayesian clustering method (Hubisz et al., 2009). The "admixture" model was used with correlated allele frequencies, and simulations were carried out with a burn-in of 100,000 generations and $\mathrm{K}$ values ranging from 2 to 6 clusters. The number of clusters $(\mathrm{K})$ was determined using STRUCTURE HARVESTER (Earl and vonHoldt, 2012).

\section{RESULTS}

A high level of polymorphism was found in ISSR markers among $V$. curassavica accessions of the AGB of Medicinal and Aromatic Plants of UFS. The location of the bands can be visualized through the images generated by the photodocumentation of the agarose gels (Figure 1). Of the 24 ISSR primers tested in this study, 14 generated informative bands. There were 149 amplified bands total, ranging from 5 to 17 bands per primer, with a mean of 11 (Table 2). Among them, 146 were polymorphic, which corresponds to $97.98 \%$ polymorphism. $I$ value indicates genetic diversity and varies from 0 to 1 , with values closer to zero having lower diversity (Silva et al., 2015). The $I$ value was equal to 0.42 , ranging from 0.25 to 0.57 for the loci of the evaluated accessions of $V$. curassavica of the AGB of Medicinal and Aromatic Plants of UFS, which suggests amplitude od medium diversity.

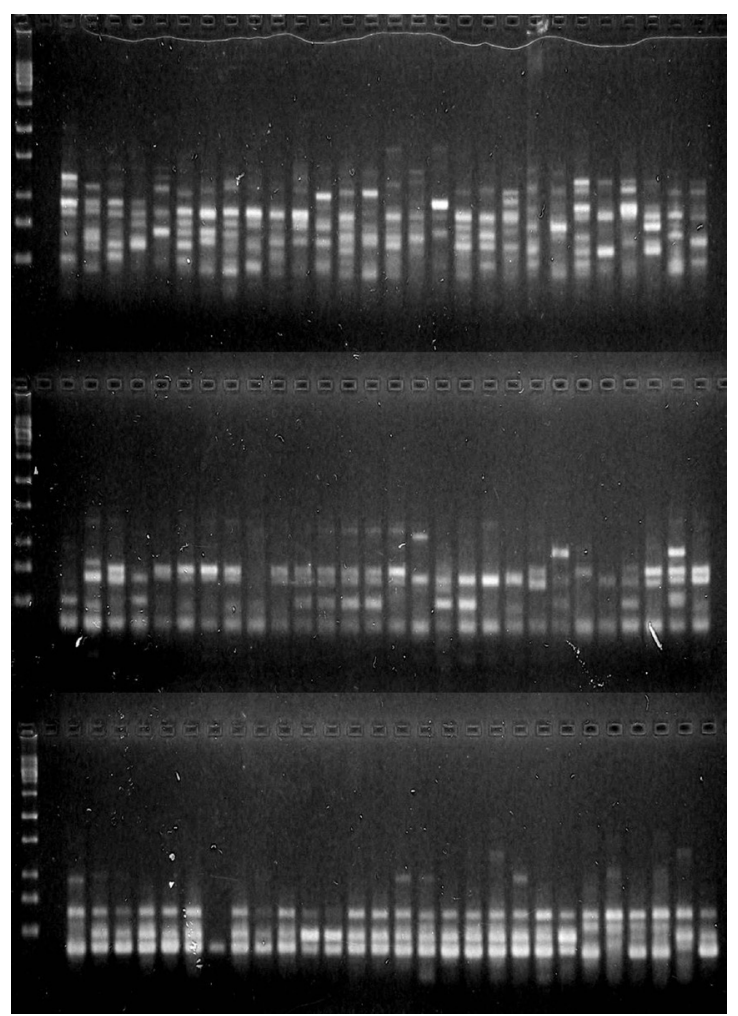

Figure 1. Dendrogram generated by UPGMA analysis of Jaccard similarity indices for 28 accessions of Varronia curassavica from the Active Germplasm Bank of Medicinal and Aromatic Plants of Universidade Federal de Sergipe.

Genetics and Molecular Research 15 (3): gmr.15038681 
Heterozygosity, which is a measure of genetic variability of a population (McManus et al., 2011), was considered low, with a mean of 0.27 . The polymorphic information content (PIC), described by Botstein et al. (1980), indicates how much the used marker shows polymorphic information in genetic diversity studies. According to Botstein et al. (1980), PIC values higher than 0.5 are very informative; those between 0.25 and 0.50 are moderately informative; and values lower than 0.25 are considered uninformative. The present study found a mean PIC of 0.27 , which is considered moderately informative. On the other hand, the MI, which is a parameter defined as the product of expected heterozygosity and proportion in multiplex, that estimates the overall quality of each molecular marker system (Powell et al., 1996), ranged from 1.22 to 5.48 with a mean of 2.88 .

The Jaccard similarity coefficient ranged from 0.24 to 0.78 , with a mean of 0.41 , which indicates relatively high genetic diversity for many pairs of accessions. Accessions VCUR-402 and VCUR-403, both from Japaratuba/Sergipe, were the most similar genetically, with an index of 0.78 . On the other hand, the pairs of accessions VCUR-001 and VCUR-503, VCUR-001 and VCUR-504, and VCUR-104 and VCUR-501 showed the lowest genetic similarity, each with an index of 0.24 . There were 15 genotype combinations with medium genetic similarity, i.e., their values ranged between 0.60 and 0.78 , and the other combinations presented low genetic similarity, with values below 0.6 (0.24 to 0.59 ; Table 3$)$.

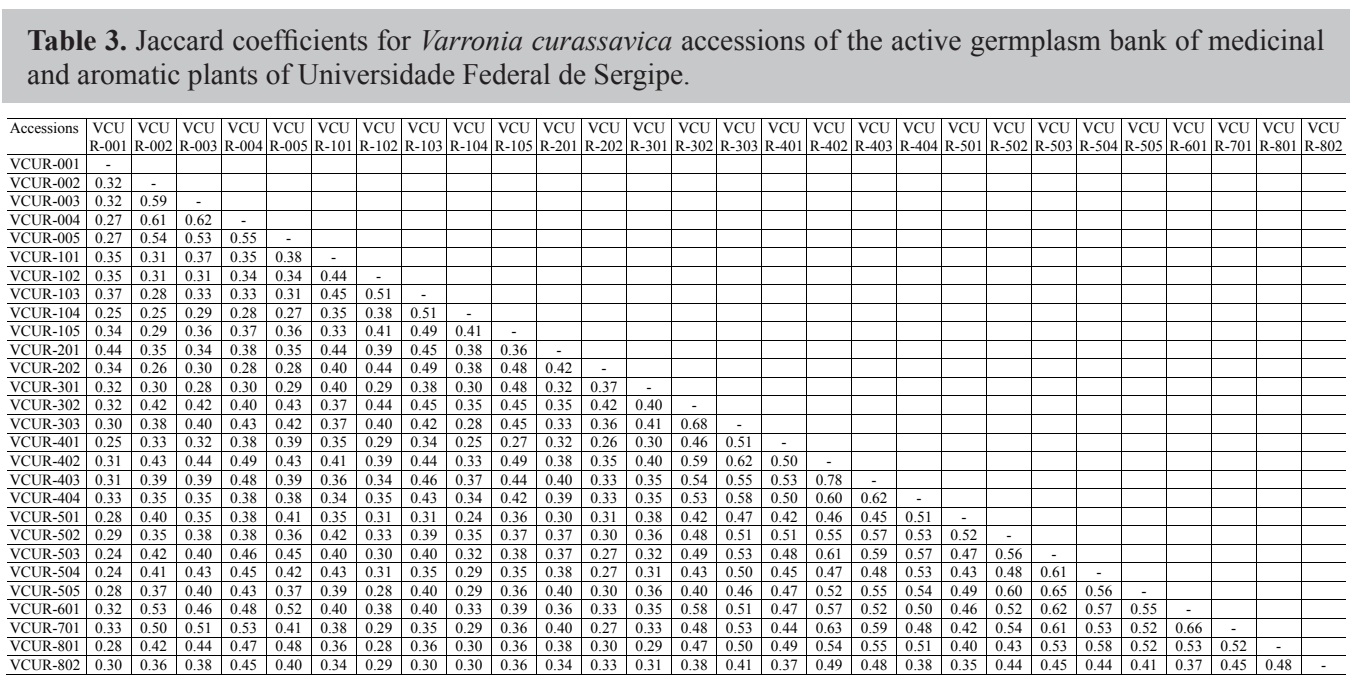

The dendrogram was divided into three major clusters (I, II and III) (Figure 2). Cluster I (including $32.15 \%$ of the accessions from the AGB) presented Jaccard coefficients below 0.5 , whereas similarities for Cluster II ( $53.57 \%$ of the AGB) were between 0.4 and 0.78 , and Cluster III (14.28 of the AGB) with similarities between 0.5 and 0.6 .

STRUCTURE effectively separated the 28 accessions in three distinct and welldefined clusters (Figure 3).

Genetics and Molecular Research 15 (3): gmr.15038681 


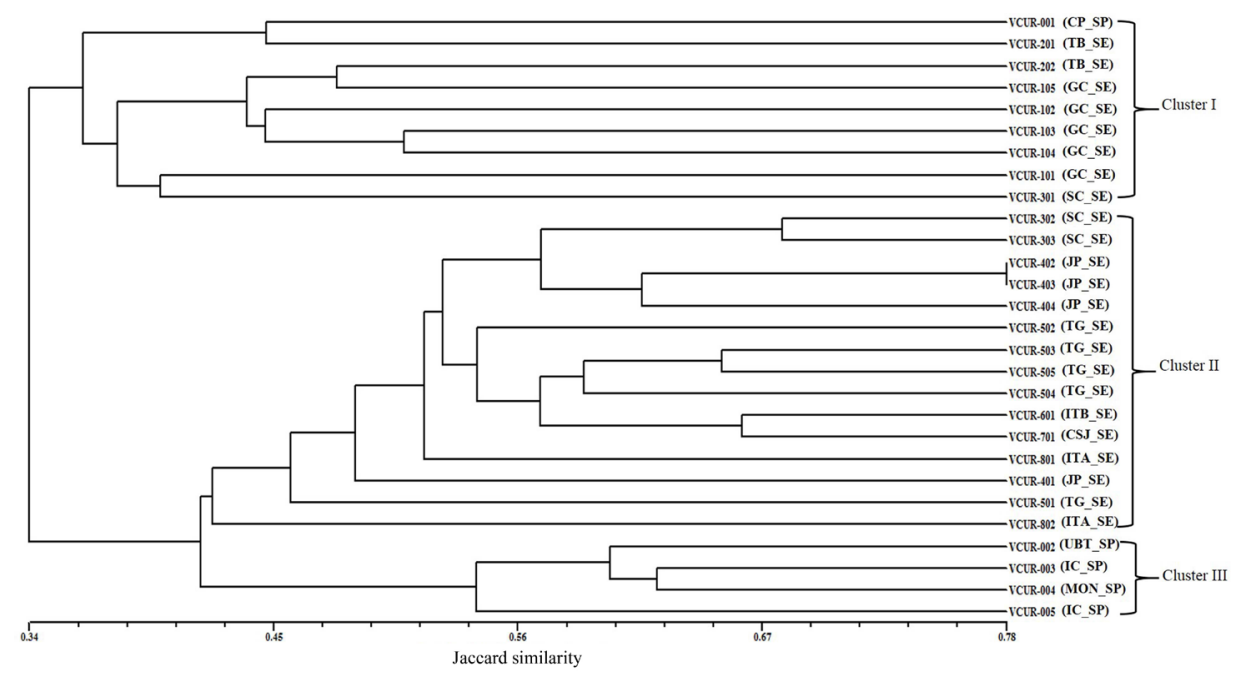

Figure 2. STRUCTURE results for 28 accessions of Varronia curassavica with $\mathrm{K}=3$. Each vertical bar represents one accession, with color indicating cluster membership.

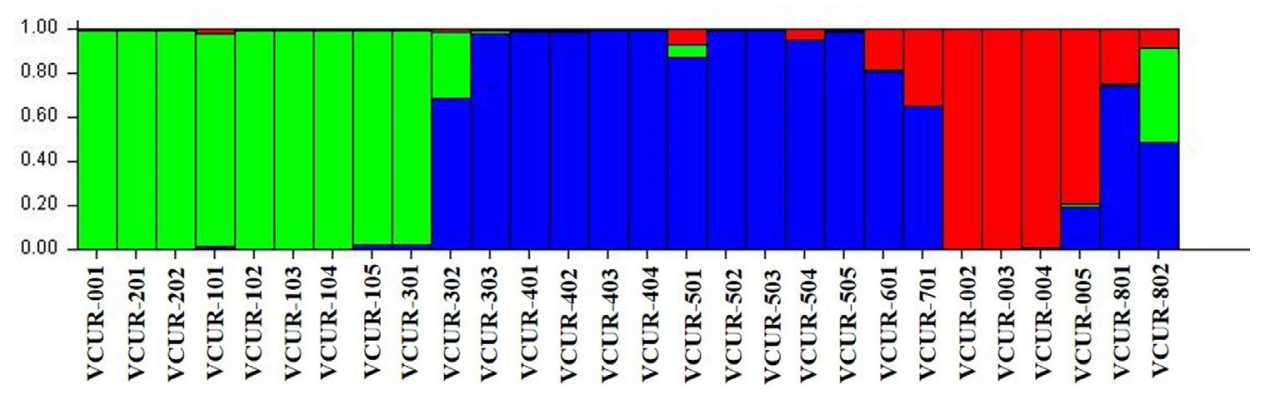

Figure 3. Principal component analysis generated by Statistica based on 149 identified bands.

\section{DISCUSSION}

Total genetic diversity of $V$. curassavica accessions is low to medium, as indicated by several diversity statistics. The genetic diversity found in the present study contrasts with the levels of chemical diversity found by Nizio et al. (2015) for five natural populations of $V$. curassavica. They detected high chemical diversity in essential oils and the division into five chemical clusters. The observed chemical diversity in essential oils can be explained in part by genetic factors. Thus, an option for expanding the genetic diversity of the AGB is the addition of some of the plants identified by Nizio et al. (2015) that produced a diversity of oil types. The addition of more ISSR or other molecular markers may identify loci that are associated with the variability seen in essential oil production for different lineages of $V$. curassavica.

According to the dendrogram (Figure 1), there is a trend of clustering according to the geographic origin of the accessions, except for accessions from São Cristóvão/SE and São Paulo/SP, which are each present in both Clusters I and II. Subcluster 1 of Cluster I has only 
accessions VCUR-001 and VCUR-201 from São Paulo/SP and Tobias Barreto/SE. Subcluster 1 of Cluster II includes all of the samples from Graccho Cardoso/SE, together with VCUR-202 from Tobias Barreto/SE. With 15 accessions from several geographical locations, subcluster 3 from Cluster II is the largest subcluster. These accessions have average and low pair-wise genetic similarity. Finally, o Cluster 4 of Cluster II consists only of additional accessions from São Paulo/SP, which have relatively high similarity within the cluster but low similarity to other accessions from São Paulo/SP in Cluster I.

The three clusters resolved by STRUCTURE are consistent with those inferred in the dendrogram. Using the same type of molecular marker, Liu et al. (2015) observed similar results, the formation of three groups in C. spinosa. Accession VCUR-802 from Itabaiana/ SE shows some affinity to each of the three groups in the STRUCTURE plot, suggesting admixture. Thus, utmost care is necessary in order to avoid losing this accession, since it may be most important for future studies on genetic improvement. Ten patchouli accessions from the AGB of medicinal and aromatic plants of UFS were efficiently identified as two distinct genetic clusters by STRUCTURE (Sandes et al., 2016), highlighting the importance of such methods in studies with AGBs of medicinal and aromatic plants.

There are no reports of studies on plants of the Cordiaceae family using ISSR markers. However, ISSR analyses of Echium vulgare L. (Boraginaceae) found lower polymorphism (93.15\%), an average of 6-17 bands per primer, a mean PIC of 0.373 (similar to that found here), and an MI of 3.1 (Dresler et al., 2015). Zhao et al. (2014) observed high genetic diversity when evaluating germplasm of 20 plants of Lilium (Liliaceae), with an average of 17-22 amplified bands per primer, but a lower $I$ (0.35). Lopez et al. (2015) evaluated genetic diversity in Omphalodes littoralis subsp gallaecica (Boraginaceae) with AFLP markers, which are also dominant, and observed heterozygosity of 0.356 and moderate genetic diversity.

Knowledge of levels of genetic diversity helps in the proper handling of an AGB, which is meant to be a sample of the genetic variation of a species (Ramalho et al., 2012). In a breeding program, this knowledge on the established accessions is of fundamental importance. The use of techniques such as assays of DNA markers can provide accurate estimates of this diversity for a portion of the genome without the potential problems of environmental influence on gene expression. According to Celestino et al. (2015), molecular tools are essential to characterize the genetic diversity of aromatic and medicinal plants. Although agronomic and chemical characteristics may distinguish different groups, expression of traits such as essential oils can be altered by environmental factors.

The genetic diversity of the collection of $V$. curassavica at UFS is low to medium. Its expansion is required, including more accessions from other locations/regions. Accession VCUR-802 is the most suitable for conservation of this species, since it represents important diversity present in the AGB. This is the first study on the genetic diversity of a collection of $V$. curassavica plants using ISSR markers, and the results are important for the conservation of this species, indicating the need to expand the diversity of the germplasm bank and producing useful information for breeding programs that may use the studied accessions.

\section{Conflicts of interest}

The authors declare no conflict of interest.

Genetics and Molecular Research 15 (3): gmr.15038681 
Genetic diversity analysis of Varronia curassavica

\title{
ACKNOWLEDGMENTS
}

\author{
Research supported by CNPq, FAPITEC/SE, CAPES, and FINEP.
}

\section{REFERENCES}

Alzate-Marin AL, Guidugli MC, Soriani HH and Mestriner MA (2005). Otimização de um método econômico e rápido de extração de DNA para quatro espécies de árvores tropicais. In: Anais do $51^{\circ}$ Congresso Brasileiro de Genética, Águas de Lindóia.

Barroso ICE, Oliveira F, Branco LHZ, Kato ETM, et al. (2002). O gênero Cordia L: botânica, química e farmacologia. Rev. Lecta 20: 15-34.

Blank AF (2013). Transformação de recursos genéticos de plantas aromáticas nativas em riqueza: o potencial do alecrimde-tabuleiro (Lippia gracilis). Hortic. Bras. 31: 512. http://dx.doi.org/10.1590/S0102-05362013000300029

Botstein D, White RL, Skolnick M and Davis RW (1980). Construction of a genetic linkage map in man using restriction fragment length polymorphisms. Am. J. Hum. Genet. 32: 314-331.

Celestino RS, Zucchi MI, Pinheiro JB, Campos JB, et al. (2015). Molecular and chemical characterization of vetiver, Chrysopogon zizanioides (L.) Roberty, germplasm. Genet. Mol. Res. 14: 9452-9468. http://dx.doi.org/10.4238/2015. August.14.9

Doyle JJ and Doyle JL (1990). Isolation of plant DNA from fresh tissue. Focus 12: 13-15.

Dresler S, Tyrka M, Szeliga M, Ciura J, et al. (2015). Increased genetic diversity in the populations of Echium vulgare L. colonising Zn-Pb waste heaps. Biochem. Syst. Ecol. 60: 28-36. http://dx.doi.org/10.1016/j.bse.2015.03.003

Earl DA and vonHoldt BM (2012). STRUCTURE HARVESTER: a website and program for visualizing STRUCTURE output and implementing the Evanno method. Conserv. Genet. Resour. 4: 359-361. http://dx.doi.org/10.1007/ $\underline{\text { s12686-011-9548-7 }}$

Feijó EVRS, Oliveira RA and Costa LCB (2014). Light affects Varronia curassavica essential oil yield by increasing trichomes frequency. Rev. Bras. Farmacogn. 24: 516-523. http://dx.doi.org/10.1016/j.bjp.2014.10.005

Gasparino EC and Barros MAVC (2009). Palinotaxonomia das espécies de Cordiaceae (Boraginales) ocorrentes no Estado de São Paulo. Rev. Brasil. Bot. 32: 33-55.

Gilbert B and Favoreto R (2012). Cordia verbenacea DC-Boraginaceae. Rev. Fitos 7: 17-25.

Goulão L and Oliveira CM (2001). Molecular characterization of cultivars of apple (Malus x domestica Borkh.) using microsatellite (SSR and ISSR) markers. Euphytica 122: 81-89. http://dx.doi.org/10.1023/A:1012691814643

Hubisz MJ, Falush D, Stephens M and Pritchard JK (2009). Inferring weak population structure with the assistance of sample group information. Mol. Ecol. Resour. 9: 1322-1332. http://dx.doi.org/10.1111/j.1755-0998.2009.02591.x

Jaccard P (1908). Nouvelles recherches sur la distribution florale. Bull. Soc. Vaud. Sci. Nat. 44: 223-270.

Liu C, Xue GP, Cheng B, Wang X, et al. (2015). Genetic diversity analysis of Capparis spinosa L. populations by using ISSR markers. Genet. Mol. Res. 14: 16476-16483. http://dx.doi.org/10.4238/2015.December.9.19

Lopez L, Retuerto R, Roiloa S, Santis X, et al. (2015). A multi-faceted approach for assessing evolutionary significant conservation units in the endangered Omphalodes littoralis subsp. gallaecica (Boraginaceae). Perspect. Plant Ecol. Evol. Syst. 17: 54-65. http://dx.doi.org/10.1016/j.ppees.2014.09.003

Lorenzi H and Matos FJA (2008). Plantas medicinais no Brasil: nativas e exóticas. 2nd edn. Editora Instituto Plantarum, Nova Odessa.

McManus C, Paiva S, Corrêa PS, Seixas L, et al. (2011). Estatísticas para descrever genética de populações. Informação Genético-Sanitária da Pecuária Brasileira (INCT). Available at [http://inctpecuaria.com.br/images/informacoestecnicas/serie_tecnica_genetica_populacoes.pdf]. Accessed February 30, 2016.

Nizio DAC, Brito FA, Sampaio TS, Melo JO, et al. (2015). Chemical diversity of native populations of Varronia curassavica Jacq. and antifungal activity against Lasiodoplodia theobromae. Ind. Crops Prod. 76: 437-448. http:// dx.doi.org/10.1016/j.indcrop.2015.07.026

Peakall R and Smouse PE (2012). GenAlEx 6.5: genetic analysis in Excel. Population genetic software for teaching and research - an update. Bioinformatics 28: 2537-2539. http://dx.doi.org/10.1093/bioinformatics/bts460

Powell W, Morgante R, Andre C, Hanafey M, et al. (1996). The comparison of RFLP, RAPD, AFLP and SSR (microsatellite) markers for germplasm analysis. Mol. Breed. 2: 225-238. http://dx.doi.org/10.1007/BF00564200

Ramalho MAP, Santos JB, Pinto CABP, Souza EA, et al. (2012). Genética na Agropecuária. 5th edn. Editora UFLA, Lavras.

Rohlf FJ (2001). NTSYSpc: numerical taxonomy system, Version 2.0. Exeter Publishing, Setauket.

Genetics and Molecular Research 15 (3): gmr.15038681 
Sandes SS, Zucchi MI, Pinheiro JB, Bajay MM, et al. (2016). Molecular characterization of patchouli (Pogostemon spp) germplasm. Genet. Mol. Res. 15: 2-12. http://dx.doi.org/10.4238/gmr.15017458

Silva AVC, Muniz EN, Almeida CS, Vitória MF, et al. (2015). Genetic diversity and sex identification in Genipa americana L. Trop. Subtrop. Agroecosys. 18: 81-86.

Yu J, Wang Y, Ru M, Peng L, et al. (2015). Genetic diversity in intraspecific hybrid populations of Eucommia ulmoides Oliver evaluated from ISSR and SRAP molecular marker analysis. Genet. Mol. Res. 14: 7417-7425. http://dx.doi. org/10.4238/2015.July.3.17

Zhao L, Liu H, Cai G and Xia M (2014). Assessment of the genetic diversity and genetic relationships of Lilium in China using ISSR marker. Biochem. Syst. Ecol. 55: 184-189. http://dx.doi.org/10.1016/j.bse.2014.03.024

Genetics and Molecular Research 15 (3): gmr.15038681 